\title{
THE ANALYSIS ON THE READINESS OF ENGLISH TEACHERS IN IMPLEMENTING AUTHENTIC ASSESSMENT IN SENIOR HIGH SCHOOLS
}

\author{
I Putu Suyoga Dharma ${ }^{1}$, Pande Agus Adiwijaya ${ }^{1}$ \\ ${ }^{1}$ STKIP Suar Bangli \\ e-mail: suyogadharma@gmail.com, adiwijayapande@gmail.com
}

\begin{abstract}
This research aimed at discovering the readiness of English teachers in implementing authentic assessment in Senior High Schools which would implement curriculum 2013 in Bangli Regency. This is an evaluative study with discrepancy analysis approach proposed by Provust. Here, the ideal implementation of authentic assessment was compared to the real implementation by the English teachers. Two English teachers in SMAN 2 Bangli and SMAN 1 Tembuku were taken as the subjects of the research. The objects involved planning, executing, and reporting of authentic assessment in the form of portfolio, performance, project, and self-assessment. To collect the data, three rubrics for planning, executing, and reporting with Likert scale were used. This research discovers: 1) in terms of planning, the teachers' readiness is classified into average, 2 ) in terms of execution, the teachers' readiness is classified into not ready, and 3) in terms of reporting, the teachers' readiness is classified into not ready. There were three main problems faced by the teachers in implementing authentic assessment, namely: a) lack of authentic assessment knowledge, b) lack of experience in designing authentic assessment, and c) lack of sharing from friends who get workshop about authentic assessment. From this research, it is suggested that a) teachers to join workshop and to read references about authentic assessment, and b) government should held more workshop about authentic assessment.
\end{abstract}

Keywords : evaluative study, discrepancy analysis, authentic assessment, planning, executing and reporting

\section{INTRODUCTION}

The low quality of education and the era demand lead the Indonesian government to change their national curriculum into Curriculum 2013. Based on Government Regulation year 2016 about Curriculum 2013, this curriculum is officially valid to be applied in all schools in the academic year 2017/2018. By the changing, the education quality can be improved so the Indonesian generation can compete and become subjects who actively produce creative and innovative works. To implement the Curriculum 2013 well, all education stakeholders, especially teachers, have to change their thinking paradigm.

One of the most crucial issues in curriculum 2013 is assessment. Based on Regulation of Education and Culture Ministry No 23 of 2016 in article 3, it is stated that assessment covers three domains, namely: cognitive, psychomotor, and affective. Non authentic assessment does not completely give information on those domains. For that reason, authentic assessment is needed as the main assessment to collect holistic information about students' learning and competency.

According to Frey, et al. (2012), assessment is authentic if it can give meaning or value which are more than the score produced by the students. Authentic assessment is started by giving complex authentic task and requiring high order thinking and students' involvement. Furthermore, Palm (2008) states that in authentic assessment, the mastery is defined by value authenticity. Someone is said to master learning concept if they can show and demonstrate it, not only knowing the concepts. From both concepts, it 
can be synthesized that authentic assessment is a process of data collection about how the students demonstrate their knowledge directly and authentically through meaningful tasks. It means that authentic assessment demands knowledge construction. The students should be involved in complex tasks which make them able to improve prior knowledge.

There are several types of authentic assessment, namely: portfolio assessment, performance assessment, project assessment, and self-assessment (Regulation of Education and Culture Ministry No 104 of 2014). According to Boric (2007), performance assessment is an assessment method covering judgement, critical thinking, and decision. It requires the students to demonstrate their performance. Meanwhile, portfolio assessment is an assessment system through collection of artifacts or works which are analyzed and reports their development from one work to the next works (Wyatt III and Looper, 1999). It is multi strategic meaning that it can be done through various steps in the implementation (McNamara and Deane, 2009). Project assessment is an assessment on certain project in the form of investigation starting from planning, executing, data analysis until report (Regulation of Education and Culture Ministry No 104 of 2014). Lastly, selfassessment is the ability to identify strengths and weaknesses as well as points for improvement in one's own performance (Zimmerman, 2002). Here, the students assess their own works reflectively.

To know the English teachers' preparation in implementing authentic assessment, an observation and interview were done in two schools (SMAN 2 Bangli and SMAN 1 Tembuku) which newly implemented Curriculum 2013 in Bangli Regency. The schools were selected because they are representative of the school in the city and village. The result of interview discovered that the teachers had prepared the lesson plan as demanded by the curriculum. The most difficult problem was on designing and implementing assessment system. The lack of practical books and workshops made them hard to understand the assessment system. However, this problem was planned to be shared in English Teacher Association in Bangli Regency.

By seeing the phenomena, this research tried to analyze and evaluate the implementation of authentic assessment done by English teachers. It was done to know the readiness of the English teachers in implementing it. The analysis covers planning, executing and reporting of authentic assessment. Furthermore, analysis on the encountered problems were also taken into account. By doing this research, three contributions are given. First, it provides general description on the implementation of authentic assessment in the new school which implemented it. Second, we know the problems faced by the teachers and giving possible solutions. Third, it provides feedback for the government about the authentic assessment implementation, so potential strategy can be prepared as a way to improve education quality.

This research focuses on four problems as follows.

1) How is the readiness of the English teacher in planning authentic assessment in Curriculum 2013?

2) How is the readiness of the English teacher in executing authentic assessment in Curriculum 2013?

3) How is the readiness of the English teacher in reporting authentic assessment in Curriculum 2013?

4) What are the problems faced by the English teachers in implementing authentic assessment in Curriculum 2013?

\section{METHODS}

This research is classified into evaluative study. It applies discrepancy analysis model proposed by Provust. Here, the ideal implementation of authentic assessment is compared with the real implementation of authentic assessment. This research was done in SMAN 2 Bangli and SMAN 1 Tembuku in the academic year 2017/2018. The schools were selected because they newly applied Curriculum 2013. Two English teachers who taught in tenth grade were selected to be samples. To collect the data, two instruments 
were used; checklist and questionnaire. The checklists were used to collect the data of teachers' readiness and the questionnaire was used to collect the data about the teachers' problems in implementing authentic assessment. There were three checklists used, namely: planning, executing, and reporting.
The data were analyzed by using descriptive statistics in which the ideal score of authentic assessment is subtracted by the real score of implementation. Then, the discrepancy score was classified based on five scale criterion referenced test presented in Table 1.

Table 1. Five Scale Criterion Referenced Test

\begin{tabular}{lll}
\hline \multicolumn{1}{c}{ Range of Score } & Category & Level of Readiness \\
\hline $\mathrm{Mi}+1.5 \mathrm{SDi}-\mathrm{Mi}+3 \mathrm{SDi}$ & Very high & Highly not ready \\
$\mathrm{Mi}+0.5 \mathrm{SDi}-\mathrm{Mi}+1.5 \mathrm{SDi}$ & High & Not ready \\
$\mathrm{Mi}-0.5 \mathrm{SDi}-\mathrm{Mi}+0.5 \mathrm{SDi}$ & Average & Average \\
$\mathrm{Mi}-1.5 \mathrm{SDi}-\mathrm{Mi}-0.5 \mathrm{SDi}$ & Low & Ready \\
$\mathrm{Mi}-3 \mathrm{SDi}-\mathrm{Mi}-1.5 \mathrm{SDi}$ & Very low & Highly ready \\
\hline
\end{tabular}

$\mathrm{Mi}=\left(\frac{1}{2}\right)$ Ideal Maximum + Ideal Minimum

Sdi $=\left(\frac{1}{6}\right)$ Ideal Maximum - Ideal Minimum

\section{FINDING AND DISCUSSION}

Finding of this research were divided into four, namely: a) the readiness of the teacher in planning authentic assessment, b) the readiness of the teacher in executing authentic assessment, c) the readiness of the teacher in reporting authentic assessment, and d) problems faced by the teachers in implementing authentic assessment. The summary of the analysis was presented in Table 2.

Table 2. The Summary of Analysis

\begin{tabular}{ccc}
\hline Aspects & Discrepancy Score & Category \\
\hline Planning & 33 & Average \\
Executing & 42 & Not ready \\
Reporting & 24 & Not ready \\
\hline
\end{tabular}

Based on Table 2, it is known that the readiness of teachers in planning is categorized into average. The readiness of teachers in executing is categorized into not ready, and the readiness of teachers in reporting is categorized into not ready. Next, based on the questionnaire, there are three main problems which were faced by the teachers in implementing authentic assessment, namely: a) lack of authentic assessment knowledge, b) lack of experience in designing authentic assessment, and c) lack of sharing from friends who get workshop about authentic assessment.

The result of data analysis shows that the teacher' readiness is average in planning authentic assessment. Meanwhile, they are not ready to execute and to report authentic assessment. In planning, four main problems were faced, namely: the less variation of authentic assessment in which the teachers only applied performance assessment, less appropriateness of instructional goal and authentic assessment applied since the teachers just copied from their friends, incomplete components of authentic assessment in terms of time allotment, goal of the assessment, and procedure of authentic assessment application, and incompleteness of authentic assessment in all language skills (authentic assessment was only used in writing). In executing, almost all planning of authentic assessments was not applied. Here, authentic assessment which is in the form of 
scoring rubric is just applied once in speaking. In reporting, four main problems were also faced, namely: less detail of analysis, no information students' development, no information about strengths and weaknesses, and less narration about the students' performance.

By analyzing the readiness level and problems, it implies that the information of students' learning is not holistic, so the students do not know their real performance in English. English language learning aims at preparing the students to be able to use English for communication. It is absolutely a continuous process relating to each other. It makes learning should be assessed correctly because it has great impact on students' learning (Kostopoulou, 2008). The assessment should be able to picture the students' development (process) and product of learning (Segers, Dochy, \& Cascallar, 2003). It merely can be done by applying authentic assessment because it is a continuous or on progress assessment. Assessment is authentic when it directly examines students' performance on worthy intellectual tasks (Wiggins \& McTighe, 2008). It requires students to demonstrate skills and competencies that realistically represent problems and situations likely to be encountered in daily life.

Authentic assessment becomes a vital element in Curriculum 2013 because it measures students' competency which covers knowledge, skill, and values based on the process and product (Kunandar, 2013). In EFL, the students do not merely answer questions in the form of multiple choice, matching, truefalse, and fill in the blank, but they also have to demonstrate their competency like making conversation based on certain topic, writing application letter, playing drama, debating, etc. In each activity, the teachers have to design authentic assessment, so the students' English competency can be known holistically. However, the teachers' knowledge about authentic assessment is a problem to design qualified authentic assessment. It is also supported by Marhaeni and Artini (2015) who found out that the teachers still need assistance and training to develop authentic assessment instruments.

The lack of knowledge about authentic assessment makes the teachers are not brave to design authentic assessment in their learning. The research done by Bordoh, et al. (2015) discovered that knowledge in authentic assessment was relatively poor. The teachers mostly cannot design and report the authentic assessment. As the requirement of Curriculum 2013, the students are encouraged to have a responsibility to the environment, interpersonal skills, and ability to think critically which is realized through studentscentered learning (Kurniasih \& Sani, 2014). If the assessment is still traditional assessment, the target of the curriculum cannot be achieved. The expectation can only be achieved by applying authentic assessment activity including Test, Observation, SelfAssessment, Peer Assessment, Performance Assessment, Portfolio Assessment, Project Assessment, Product Assessment, and Journal Assessment. It becomes a great problem if the teachers cannot design and apply authentic assessment.

Relating to the encountered problems, it has been proposed to English Teacher Association of Bangli Regency. However, the association is still focus on teaching approach (scientific approach). The issue of assessment is planned to be discussed this year. Furthermore, problems of communication with the teachers actually exists for long time. The teachers actually try to ask the teachers who join the seminar, but they just give the paper. If they were not asked, they just keep silent. It makes the workshop materials are hard to be accessed by the teachers.

\section{CONCLUSION}

Authentic assessment is an essential element of EFL. However, the teachers still cannot implement it ideally. It seems that they are not ready yet to implement it, starting from planning, executing and reporting. Three main problems which are faced by the teachers in implementing authentic assessment, namely: a) lack of authentic assessment knowledge, b) lack of experience in designing authentic assessment, 
and c) lack of sharing from friends who get workshop about authentic assessment. It is recommended for the teachers to do discussion and sharing in MGMP (English Teacher Organization) on how to solve the problems about authentic assessment. The school principals, supervisors, Education Department of Bali Province should pay special attention on the authentic assessment, especially in designing authentic assessment.

\section{GRATITUDE}

Thanks for the Ministry of Research, Technology, and HighEducation for giving fund for this research. Hopefully, this research can be benefecial for the development of education and English teachers' professionalism in managing assessement in Curriculum 2013.

\section{REFERENCES}

Bordoh, A., Eshun, I., Quarshie, A.M., Bassaw, T.K., \& Kwarteng, P. (2015). Social studies teachers' knowledge base in authentic assessment in selected senior high schools in the central region of ghana. Journal of Social Science and Humanities, 1(3), 249257

Boric, G.D. (2007).Effective teaching methods: Research-based practice. New Jersey: Pearson Merril Prentice Hall

Frey, Bruce B., Schmitt, Vicki L., \& Allen, Justin P. (2012). Defining Authentic Classroom Assessment. Practical Assessment, Research \& Evaluation, 17(2), 1-18

Kostopoulou, S. (2008). Learner self- assessment: innovation and change in the culture of assessment. Journal of Postgraduate Research, Trinity College Dublin, 7, 119135.

Kunandar. (2013). Authentic Assessment. Jakarta: PT. Raja graffito Persada.

Kurniasih, I., \& Sani, B. (2014). Implementasi Kurikulum 2013: Konsep dan Penerapan. Surabaya: Kata Pena

Marhaeni, A.A.I.N and Artini, L.P. (2015). Asesmen authentic dan pendidikan bermakna: Implementasi kurikulum 2013. Jurnal Pendidikan Indonesia, 4(1), 499-511
McNamara and Deane. (2009) Assessing students' knowledge. Cambriadge: Cambridge University Press

Palm, Torulf. 2008. Performance Assessment and Authentic Assessment: A Conceptual Analysis of the Literature. Practical Assessment, Research \& Evaluation ISSN 1531-7714 Volume 13, Number 4, April 2008.

Regulation of Education and Culture Ministry no 104 year 2014

Regulation of Education and Culture Ministry No 23 year 2016

Segers, M., Dochy, F., \& Cascallar, E. (Eds.). (2003). Optimising new modes of assessment: In search of qualities and standards. Boston: Kluwer Academic Publishers.

Wiggins, G., \& McTighe, J. (2008). Put understanding first. Educational Leadership, 65(8),36 41

Wyatt III, R.L \& Looper, S. (1999). So You Have to Have A Portfolio, a Teacher's Guide to Preparation and Presentation. California: Corwin Press Inc.

Zimmerman, B. J. (2002). Becoming a selfregulated learner: An overview. Theory into Practice, 41, 64-70. 